\title{
Ozone trends at northern mid- and high latitudes - a European perspective
}

\author{
N. R. P. Harris ${ }^{1,12}$, E. Kyrö ${ }^{2}$, J. Staehelin ${ }^{3}$, D. Brunner ${ }^{4}$, S.-B. Andersen ${ }^{5, *}$, S. Godin-Beekmann ${ }^{6}$, S. Dhomse ${ }^{7}$, \\ P. Hadjinicolaou ${ }^{8,9}$, G. Hansen $^{10}$, I. Isaksen ${ }^{11}$, A. Jrrar ${ }^{12, * *}$, A. Karpetchko ${ }^{2}$, R. Kivi ${ }^{2}$, B. Knudsen ${ }^{5}$, P. Krizan ${ }^{13}$, \\ J. Lastovicka ${ }^{13}$, J. Maeder ${ }^{3}$, Y. Orsolini ${ }^{10}$, J. A. Pyle ${ }^{12}$, M. Rex ${ }^{14}$, K. Vanicek $^{15}$, M. Weber ${ }^{7}$, I. Wohltmann ${ }^{14}$, \\ P. Zanis ${ }^{16}$, and C. Zerefos ${ }^{8}$ \\ ${ }^{1}$ European Ozone Research Coordinating Unit, University of Cambridge, UK \\ ${ }^{2}$ Arctic Research Centre of Finnish Meteorological Institute, Sodankylä, Finland \\ ${ }^{3}$ Swiss Federal Institute of Technology, Zurich, Switzerland \\ ${ }^{4}$ Empa, Swiss Federal Laboratories for Materials Testing and Research, Dübendorf, Switzerland \\ ${ }^{5}$ Danish Meteorological Institute, Copenhagen, Denmark \\ ${ }^{6}$ CNRS-Service d'Aéronomie, Université Pierre et Marie Curie, Paris, France \\ ${ }^{7}$ University of Bremen, Bremen, Germany \\ ${ }^{8}$ National and Kapodistrian University of Athens, Greece \\ ${ }^{9}$ Frederick Institute of Technology, Nicosia, Cyprus \\ ${ }^{10}$ Norwegian Institute for Air Research, Norway \\ ${ }^{11}$ University of Oslo, Oslo, Norway \\ ${ }^{12}$ Centre for Atmospheric Science, University of Cambridge, UK \\ ${ }^{13}$ Institute of Atmospheric Physics, Academy of the Sciences of the Czech Republic \\ ${ }^{14}$ Alfred Wegener Institute for Polar and Marine Research, Potsdam, Germany \\ ${ }^{15}$ Czech Hydrometeorological Institute, Czech Republic \\ ${ }^{16}$ Department of Meteorology - Climatology, Aristotle University of Thessaloniki, Thessaloniki, Greece \\ * now at: the Danish and Greenlandic Survey, Copenhagen, Denmark \\ ** now at: British Antarctic Survey, Cambridge, UK
}

Received: 11 May 2007 - Revised: 19 October 2007 - Accepted: 9 January 2008 - Published: 28 May 2008

\begin{abstract}
The EU CANDIDOZ project investigated the chemical and dynamical influences on decadal ozone trends focusing on the Northern Hemisphere. High quality longterm ozone data sets, satellite-based as well as ground-based, and the long-term meteorological reanalyses from ECMWF and NCEP are used together with advanced multiple regression models and atmospheric models to assess the relative roles of chemistry and transport in stratospheric ozone changes. This overall synthesis of the individual analyses in CANDIDOZ shows clearly one common feature in the $\mathrm{NH}$ mid latitudes and in the Arctic: an almost monotonic negative trend from the late 1970s to the mid 1990s followed by an increase. In most trend studies, the Equivalent Effective Stratospheric Chlorine (EESC) which peaked in 1997 as a consequence of the Montreal Protocol was observed to describe
\end{abstract}

Correspondence to: N. R. P. Harris

(neil.harris@ozone-sec.ch.cam.ac.uk) ozone loss better than a simple linear trend. Furthermore, all individual analyses point to changes in dynamical drivers, such as the residual circulation (responsible for the meridional transport of ozone into middle and high latitudes) playing a key role in the observed turnaround. The changes in ozone transport are associated with variations in polar chemical ozone loss via heterogeneous ozone chemistry on PSCs (polar stratospheric clouds). Synoptic scale processes as represented by the new equivalent latitude proxy, by conventional tropopause altitude or by $250 \mathrm{hPa}$ geopotential height have also been successfully linked to the recent ozone increases in the lowermost stratosphere. These show significant regional variation with a large impact over Europe and seem to be linked to changes in tropospheric climate patterns such as the North Atlantic Oscillation. Some influence in recent ozone increases was also attributed to the rise in solar cycle number 23. Changes from the late 1970s to the mid 1990s were found in a number of characteristics of the Arctic

Published by Copernicus Publications on behalf of the European Geosciences Union. 


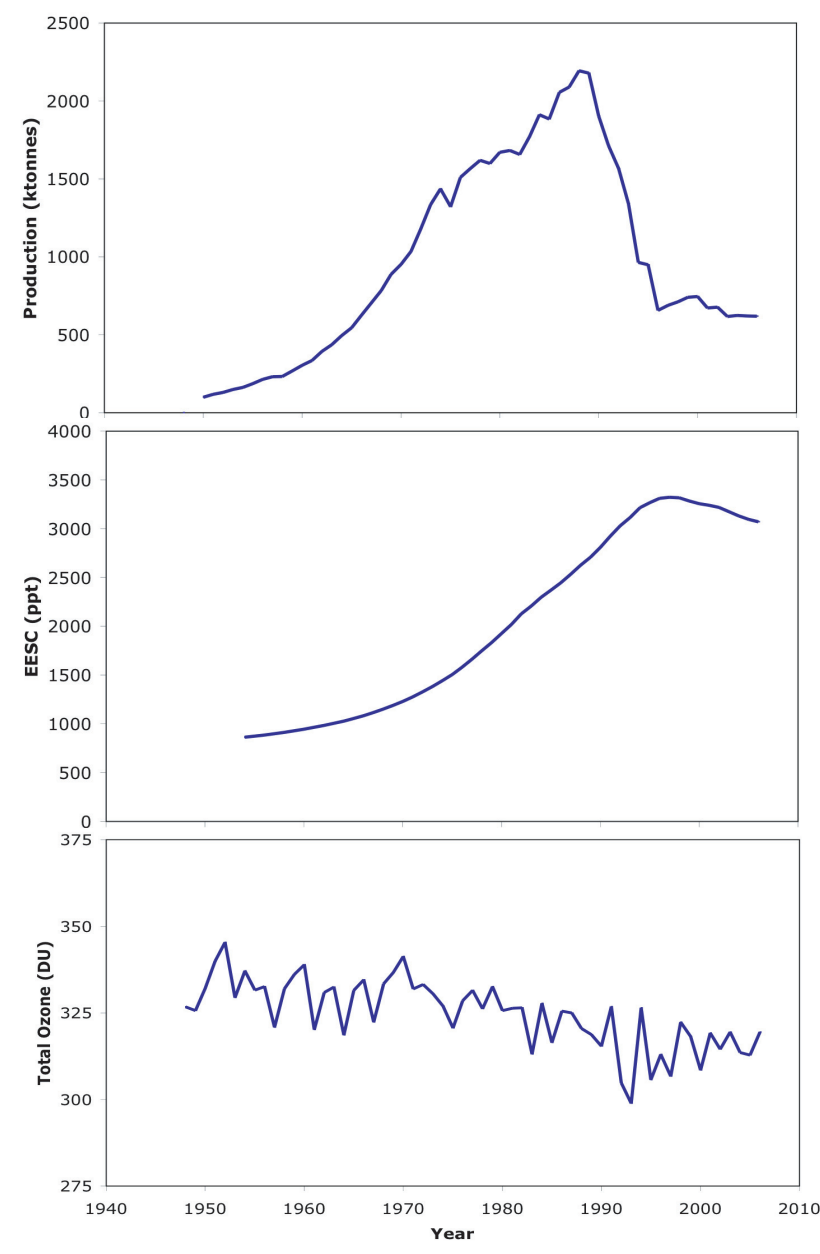

Fig. 1. Top: Global production of ODS. Middle: Ability of ODS to deplete stratospheric ozone (Equivalent Effective Stratospheric Chlorine - EESC) (solid) in comparison with a linear trend starting in 1970 (dashed). EESC is an overall measure of chemical ozone depletion taking into account the lifetimes and the chemical ozone depleting potentials of the individual chemical species. Bottom: Annual mean values of the total ozone series of Arosa (Switzerland) and relevant processes influencing total ozone at Northern mid-latitudes.

vortex. However, only one trend was found when more recent years are also considered, namely the tendency for cold winters to become colder.

Keywords. Atmospheric composition and structure (Middle atmosphere - composition and chemistry) - Meteorology and atmospheric dynamics (Middle atmosphere dynamics)

\section{Introduction}

The possible depletion of the ozone layer was raised in the early 1970s (Crutzen, 1971; Johnston, 1971; Molina and Rowland, 1974; Stolarski and Cicerone, 1974). In the mid to late 1980s decreasing ozone amounts were observed at polar and middle latitudes (Farman et al., 1985; Rowland et al., 1988) which were related to the release of man-made Ozone Depleting Substances (ODS) such as chlorofluorocarbons and Halons. Meanwhile, in response to the threat of ozone destruction, the Vienna Convention was signed in 1985. The Montreal Protocol which limits the emissions of ODS was signed in 1987 and has subsequently been revised on six occasions. The implementation of the Montreal Protocol, its adjustments and amendments has successfully resulted in reduced global production of ODS (and, with a small delay, emissions) from the end of the 1980s (Fig. 1, top panel). In turn, this has led to a more recent decline of the effective stratospheric chlorine loading (EESC) by about $6 \%$ since its peak in the late 1990s (Fig. 1, middle panel). In the Arctic and Antarctic, the turnaround is later (1998-2000) and the rate of decrease slower (Newman et al., 2006).

The world's longest total ozone series (Arosa, Switzerland) shows the typical features of ozone in the Northern mid-latitudes (Fig. 1, bottom panel). The total ozone decreased from the early 1970s until the mid-1990s. After the record low ozone values in the early 1990s (related to the eruption of Mt. Pinatubo in 1991 (e.g. Harris et al., 1997)) total ozone at northern mid-latitudes has increased for more than a decade. The decline up to the mid-1990s has been commonly attributed to chemical ozone depletion caused by the increasing concentrations of ODS. Now that the peak in EESC has passed, it is important to know for both scientific and political reasons whether the implementation of the Montreal Protocol is effective in terms of stratospheric ozone. However, the attribution of ozone trends to changes in ODS emission is a difficult task because many factors contribute to ozone variability and trends, in particular at midlatitudes. They include:

- Large volcanic eruptions;

- Arctic ozone depletion;

- Long-term climate variability;

- Changes in the stratospheric circulation; and

- Eleven year solar cycle.

Analysing the existing measurement record in order to quantify how the Montreal Protocol and its amendments have affected the ozone layer is thus hard and requires great care. An improved understanding of these factors is needed to provide reliable predictions of stratospheric ozone. In particular, quantification of dynamical influences on stratospheric ozone changes was highlighted as an outstanding issue in ozone research, for which the level of scientific understanding was quoted as medium/medium-low in WMO 2002 (Table 4.5 in Chipperfield and Randel, 2003). This uncertainty strongly limits the interpretation of the past evolution of the 
ozone layer and limits our confidence in predictions of its future evolution.

The EU CANDIDOZ project (Chemical And Dynamical Influences on Decadal Ozone Change) from 2002-2005 addressed these issues. The major objective was to separate and quantify the individual factors contributing to past ozone variability and trends in the Northern Hemisphere. Here we synthesize the main findings of this project with respect to the policy-related questions outlined above. We do not attempt to describe all the work performed during the project which is described in the CANDIDOZ final report (available from fmiarc.fmi.fi/projects/candidoz/) and in published papers, although a brief summary is given in Sect. 2 to show the importance of this "underpinning" work to the main results presented here. Section 3 presents the results most relevant to identifying and understanding of the effect of the Montreal Protocol on the ozone layer and Sect. 4 contains a discussion and summary. For the most part we make reference to the 2002 WMO-UNEP Ozone Assessment, and particularly to the chapter on global ozone (Chipperfield and Randel, 2003), as that represented the scientific understanding at the start of CANDIDOZ. The 2006 Assessment was written during the preparation of this paper and is only referred to for specific points.

\section{Approach}

We adopted a multi-faceted approach with different research groups involved in the:

- production and re-evaluation of ozone data sets;

- investigation of long-term stratospheric changes using ERA-40 re-analyses;

- development and use of process-based statistical approaches to describe past ozone changes;

- use of atmospheric models.

\subsection{Ozone data sets}

The available knowledge concerning the long-term evolution of the ozone layer comes from ground-based measurements based on the Dobson and Brewer instruments coordinated in the WMO's Global Atmospheric Watch programme and from measurements by satellite instruments. The nearglobal coverage provided by the satellite instruments started in 1979 and complements the longer-term information from the ground-based measurements. The two systems provide essential quality control for each other and so are at most quasi-independent. Constant vigilance is required to assess and improve the quality of the ozone data sets in the light of new knowledge and instrumental understanding.
In CANDIDOZ groups worked on the following topics.

- Re-evaluation of the long-term total ozone series at (i) Troms $\varnothing$, Norway $\left(70^{\circ} \mathrm{N}, 19^{\circ} \mathrm{E}\right), 1935-1972$ based on measurements from a Fery spectrograph and from a Dobson spectrophotometer (Hansen and Svenoe, 2005); (ii) Svalbard, Spitzbergen, Norway $\left(79^{\circ} \mathrm{N}, 12^{\circ} \mathrm{E}\right)$, 1950-1962 based on measurements of a Dobson instrument (Vogler et al., 2006); and (iii) Hradec Králové, Czech Republic $\left(50^{\circ} \mathrm{N}, 16^{\circ} \mathrm{E}\right), 1962-2003$, based on careful comparison of measurements of Dobson and Brewer spectrophotometers (Vanicek et al., 2003; Vanicek, 2006).

- Re-evaluation of the ESA GOME total ozone record from 1996 to 2003 using ozone measurements produced by the new WFDOAS retrieval algorithm (Weighting Function DOAS) (Coldewey-Egbers et al., 2004, 2005; Weber et al., 2005).

- Re-evaluation of Arctic ozone sonde records from 8 Arctic stations in Europe and Canada $\left(60^{\circ}-80^{\circ} \mathrm{N}\right)$ from 1989 to 2003 (Kivi et al., 2007).

- Comparison between satellite and ground-based total ozone measurements (Vanicek, 2006; Weber et al., 2005).

- Production of the CANDIDOZ Assimilated Threedimensional Ozone data set (CATO) with complete global coverage and daily resolution from 1979 to 2004 based on the NIWA combined TOMS/GOME/SBUV satellite total ozone measurements and ERA-40 meteorology. CATO is a unique data set with internally consistent fields for the total column and the vertical distribution of ozone (Brunner et al., 2006a).

\subsection{Long-term stratospheric changes using ERA-40 re-} analyses

The reanalysis of global meteorological data (ERA-40) by the European Centre for Medium Range Weather Forecasts (ECMWF) was completed shortly after CANDIDOZ started (Uppala et al., 2005). The availability of these reanalyses, with their reasonably high degree of internal consistency, allowed us to investigate dynamic influences on decadal timescales. A particular focus was on the dynamical influences on the Arctic stratosphere (Karpetchko et al., 2005) and the relation between Northern Hemisphere total ozone fields and meteorological patterns such as the North Atlantic Oscillation (Orsolini and Doblas-Reyes, 2003; Orsolini, 2004).

The ERA-40 data were also used to run CTMs for more than 40 years. This period covers a decade of the chemically undisturbed stratosphere, the period of increasing chemical ozone depletion and the last decade in which ozone in northern mid-latitude increased. Long numerical simulations 
have the potential to quantify the importance of the different chemical and dynamical processes affecting the ozone layer. While good technical progress was made in using ERA-40 with a number of CTMs, less progress was made in using models to understand past ozone trends than was originally hoped. Nevertheless long-term simulations with both simplified and full chemical descriptions were made and initial interpretations have been performed (Hadjinicolaou et al., 2005).

2.3 Process-based statistical approaches to describe past ozone changes

In the standard linear multiple regression approach used in ozone trend analyses (e.g. WMO, 2003), the measured (monthly mean) ozone values $(Y(t))$ are modelled using

$Y(t)=a(t)+b(t) \cdot t+\sum_{j=1}^{N} c_{j}(t) \cdot X_{j}(t)+e(t)$

Here $a(t)$ is a constant, $c_{j}$ are coefficients for terms describing natural variability using explanatory variables, $X_{j}(t)$; autocorrelations in the residuals $e(t)$ are calculated to determine realistic confidence intervals. For the description of trends, $b(t)$, the following options are used:

1. Single linear trend vs. time ("hockey stick"): This approach was commonly used in earlier ozone assessments and the determined trends were usually attributed to anthropogenic ozone depletion. This description is still useful to characterize the long-term changes, but this concept cannot describe the influence of the time evolution of ODS after the middle of the 1990s when EESC started to deviate from the almost linear increase (Fig. 1). (N.B. The term "hockey stick" is used because the original analyses of ground-based data which started before 1970 looked for a change in ozone after 1970 compared to the undisturbed (i.e. low EESC) behaviour before 1970.)

2. Two linear trends (“double hockey stick”): The first linear downward trend starts at the beginning of the series (or at the beginning of the 1970s), and an additional linear trend is introduced (starting from the inflection point) to describe the influence of the Montreal Protocol. The second slope term includes information on (i) whether the second linear slope significantly deviates from the first one and (ii) whether the second period shows a significant upward trend. However, this approach is rather empirical and the series to fit the second linear trend is short.

3. The ozone time series can be fitted to EESC instead of the linear trend terms ("EESC model"). This approach is based on a physical quantity and the fit of explanatory variables is based on the entire series. However, the shape of the EESC curve may not be wholly appropriate as chemical ozone loss resulting from ODS does not simply linearly depend on EESC, but also on other factors such as aerosol surface area and PSC existence.

In the first two cases, the trend term represents that part of the ozone tendency which cannot be explained by other (natural) factors, and which is therefore interpreted as being due to anthropogenic activity. In the third case the expected anthropogenic influence lies in the rate of change of the EESC term which, after solving the coefficient of EESC term, directly gives the modeled anthropogenic part of the rate of change of ozone.

This type of multiple linear regression has been the most common approach used to determine trends in ozone measurements (Chipperfield and Randel, 2003; Chipperfield and Fioletov, 2007, and references therein). Up until a few years ago, the underlying assumption was that any longterm change was linear and caused by chemical ozone depletion resulting from the then steadily increasing concentrations of ODS. Two factors have caused a revision in this approach. First, ODS concentrations stopped increasing. Second, the influence of dynamic influences on ozone on decadal timescales became more apparent (e.g. Hood et al., 1997; Steinbrecht et al., 1998). However, while correlations between ozone and a number of meteorological quantities (such as tropopause height) were statistically significant, it was impossible to link these unambiguously to particular physical processes (Chipperfield and Randel, 2003).

A real effort has been made to produce process-based indicators of dynamic and chemical influences which can be used in statistical models (as new or additional $X_{j}(t)$ in the above formulation) in order to aid the attribution of past ozone changes. The availability of the ERA- 40 analyses was of great benefit as long, internally consistent time series of these dynamic quantities are required for the statistical analyses (Wohltmann et al., 2005). Three particular proxies were routinely used in the analyses described in the next section.

First, the volume of polar stratospheric clouds (PSC) correlates closely with the accumulated chemical ozone loss in the Arctic vortex in each winter (Rex et al., 2004, 2006). This quantity shows large interannual variability depending on the specific conditions in the polar vortex each winter. Over the last decades the potential for chemical ozone depletion has changed significantly (Fig. 1) and so the PSC volume was scaled by the EESC in order to investigate the multi-decadal influence of ozone depletion in the Arctic vortex (Kivi et al., 2007). Such an approach is also used to estimate the influence of polar depletion at mid-latitudes.

Second, total ozone is locally affected by vertical and horizontal displacements (e.g. Hood et al., 1997, Steinbrecht et al., 1998; Weiss et al., 2001), but it has proven hard to develop meaningful proxies which uniquely refer to particular physical processes (Chipperfield and Randel, 2003). This was an important aim for us, and a new proxy was developed to describe these synoptic scale variations by using an ozone profile climatology in equivalent latitude (horizontal) 
and isentropic (vertical) coordinates that is fit to total column measurements using the equivalent latitudes and potential temperatures derived daily at each location (Wohltmann et al., 2005, 2007).

Third, the strength of the stratospheric mean meridional circulation, i.e. the relatively slow movement of air from the tropics to higher latitudes, determines how much ozone is present above mid- and high latitudes in each late winter and spring, and so is a strong influence on the interannual variability in ozone (Fusco and Salby, 1999; Randel et al., 2002) and polar ozone chemistry (Weber et al., 2003). Time series of the measure of this circulation, the Eliassen-Palm (EP) flux, were calculated from ERA-40 and NCEP data and used in a number of studies.

Finally, a neural network approach was used for trend analysis of seven European stations with long total ozone records. This new technique was to our knowledge not applied in ozone trend analysis before (Metelka et al., 2005).

\section{What have we learnt about long-term ozone trends?}

There are three main issues relating to long term changes in Northern Hemisphere ozone which are of interest to the public and to policy-makers:

- The causes of past ozone changes at northern midlatitudes;

- Long-term changes in the Arctic stratosphere; and

- The implications for future ozone.

Here we attempt to synthesise the results from a number of studies performed within CANDIDOZ in the context of all research in this area. The first two issues are addressed in this section, and the implications, including the impact of the Montreal Protocol to date, are discussed in Sect. 4. However, before doing so, the concept of ozone recovery is discussed.

The term "recovery" has been used in a number of different ways (Hofmann and Pyle, 1999; Weatherhead et al., 2000; Reinsel et al., 2002) and there is on-going disagreement and/or confusion about what is its most suitable definition, even among specialists. Should it be defined according to halocarbons, ozone or UV radiation? Should it be defined as a return of any or all of these to pre-1980 ozone levels? Should it be defined as a clear reversal of past trends? Or as a clear reduction in the magnitude of past trends? Does it matter what the cause of any change in the trend of ozone or UV radiation is? Should it be linked to the actions taken under the Montreal Protocol? Does it matter that the atmosphere is unlikely to return to its pre-1980 condition? To complicate matters further, recovery (particularly for ozone and UV radiation) may occur in some regions or at some times of year, and not at others. For example, much of the early work on recovery focused on the regions and seasons where the signs of recovery might first be observed, particularly at high altitudes and in polar regions (e.g. Hofmann and Pyle, 1999).

From a political perspective it makes sense to consider recovery in terms of ozone recovery from anthropogenic influences. In this light, the first stages of recovery, namely reductions in ODS emissions and the subsequent turnaround and decrease in EESC are already in the past. The next stages - the slowing of the ozone decline and the reducing chemical impact of ODS (often called "turnaround") - have been strongly debated. Our scientific understanding tells us that we must be passing through these stages around now, but we need to demonstrate it unequivocally. The final stage, the "full" recovery of ozone, is clearly in the future. The main points of current discussions are what the state of the atmosphere will be in the coming decades and what level of EESC will provide "full" recovery of ozone. The commonly used threshold is 2000 pptv ( $\mathrm{Cl}$ equivalent), but this is an arbitrary choice which coincides with the start of the modern satellite record and our scientific understanding tells us that ozone depletion must have occurred at lower EESC levels. In the following sections, we concentrate on whether the influence of the reduced ODS emissions can be seen in the observational ozone record. The issue of recovery is discussed in more detail in the 2006 WMO-UNEP Ozone Assessment (WMO, 2007). The contrasting behaviour of the ozone evolution at mid and high latitudes in the two hemispheres is not considered further here, although it does provide valuable constraints on interpretations of the ozone record, particularly where dynamic factors are concerned (e.g. Krizan and Lastovicka, 2006; Stolarski and Frith, 2006).

3.1 The causes of past ozone changes at northern midlatitudes

The CANDIDOZ ozone trend studies use a variety of measurement data sets and statistical models. However, their results are broadly consistent and the major findings are summarised below. Figure 2, based on the CANDIDOZ Assimilated Three-dimensional Ozone (CATO - Brunner et al., 2006a, b), shows the major influences on the total ozone trends over northern mid-latitudes. (Note that the influence of the QBO is not shown here as it affects the short-term variability rather than the longer-term behaviour. Similarly the annual cycle is not discussed.) In the following, we discuss first the well-documented ozone decline, then the recent increase and whether it constitutes recovery resulting from EESC changes, and finally the link between ozone and tropospheric climate patterns.

\subsubsection{Ozone evolution prior to mid-1990s}

For this period, the CANDIDOZ studies have mainly improved the statistical attribution of the trends to the different causes. The major cause of the ozone decline over northern mid-latitudes $\left(36^{\circ}-60^{\circ} \mathrm{N}\right)$ from 1979 to the mid-1990s was 
(a) March, April \& May

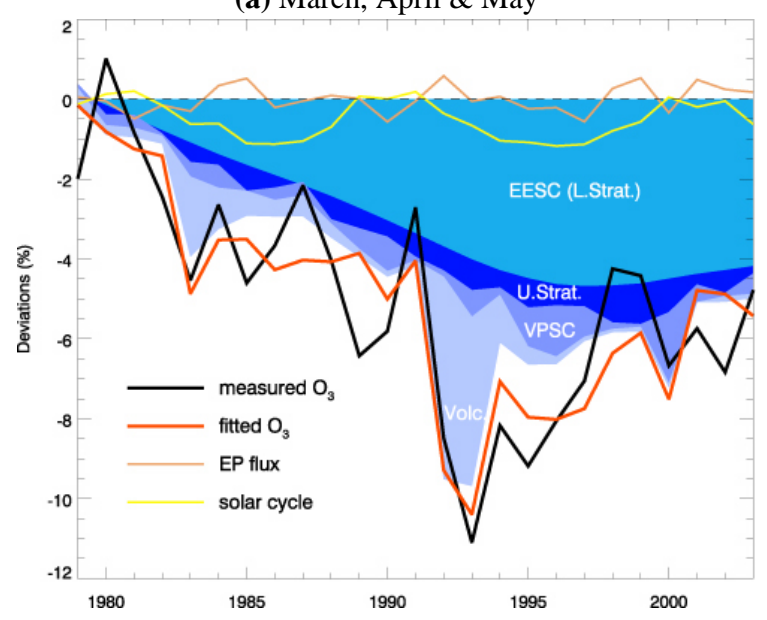

(c) September, October \& November

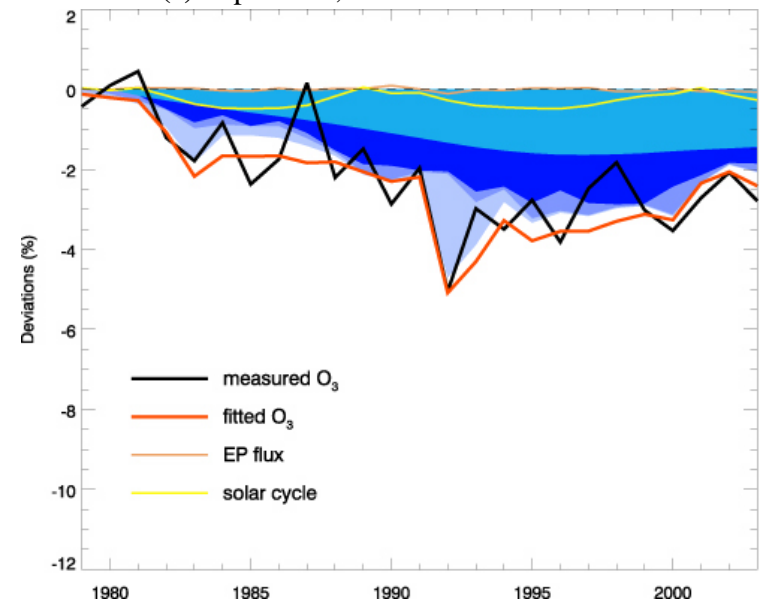

(b) June, July \& August

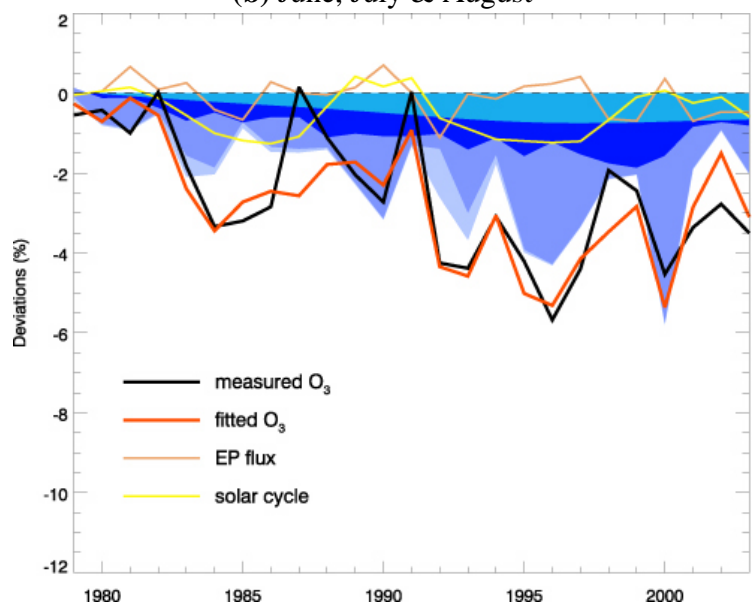

(d) December, January and February

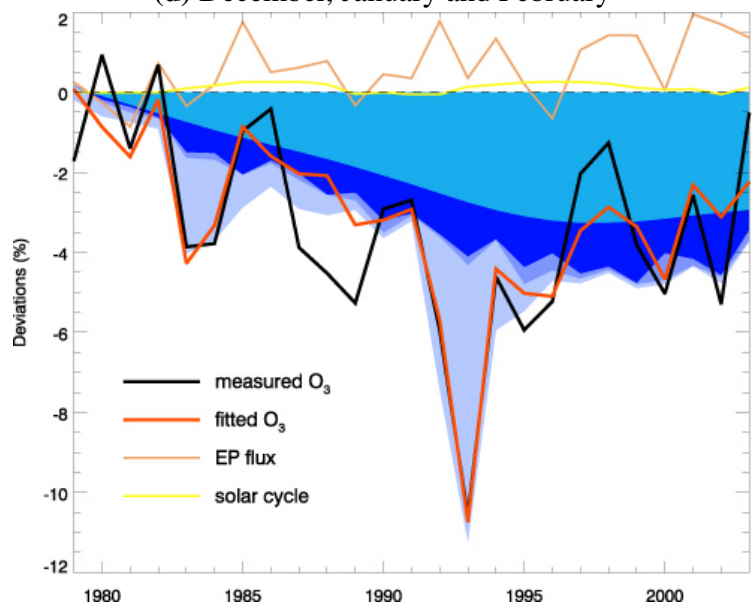

(e) annual

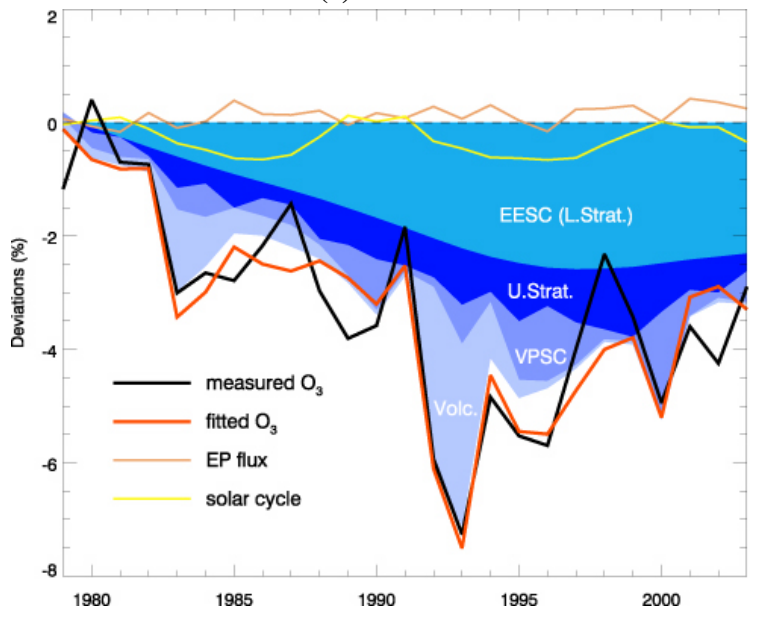

Fig. 2. Annual and seasonal evolution of northern mid-latitude $\left(36^{\circ}-60^{\circ} \mathrm{N}\right.$ equivalent latitude) total ozone anomalies from 1979 to 2003 calculated by a multiple regression analysis of the CATO data set (Brunner et al., 2006a, b). U.Strat is calculated directly from SBUV version 8 profile data above $10 \mathrm{hPa}$ (Bhartia et al., 2004) as ozone at these altitudes is not reconstructed in CATO. The contributions attributed to non-polar ozone loss in the lower stratosphere (EESC (L.Strat)), upper stratospheric ozone loss (U.Strat), polar loss (VPSC, but actually VPSC*EESC) and volcanic eruptions (Volc.) are shown as coloured areas stacked on top of each other. The contributions from EP flux and solar cycle are shown as orange and yellow lines, respectively. All anomalies are scaled to the 1979-1980 mean. The observed anomalies and the fit of the statistical model are shown in black and red lines, respectively. 
the increase in EESC (Fig. 2). The biggest signal found here is the effect assumed to depend linearly on EESC which was responsible for an annually averaged decrease of about $2.5 \%$ in the column over this period. Losses in the upper stratosphere (resulting solely from homogeneous chemistry) contributed a further $1 \%$ to the column loss, and those related to polar ozone depletion contributed up to a further $2 \%$, though with considerable inter-annual variability. The total maximum effect of ODS (i.e. EESC (L.Strat) + U.Strat + VPSC in Fig. 2) was about 5\% in 1995, 1996 and 2000, all years with large Arctic ozone losses. In an analysis of Arosa Umkehr data from 1956-2004, Zanis et al. (2006) find statistically significant negative ozone trends from 1970 to 1995 in the upper stratosphere (above $32.6 \mathrm{~km}$ ) throughout the course of the year as well as in the lower stratosphere (below $23.5 \mathrm{~km}$ ) mainly during winter to spring. The latter are partially attributed to dynamical changes. The overall picture of the trends at northern mid-latitudes is now well-established.

The Mt. Pinatubo eruption in 1991 had a significant influence on total ozone over northern mid-latitudes from late 1992 to 1994, and the few years following the Mt. Pinatubo eruption exhibited the lowest ozone values observed over northern mid-latitudes. This effect was larger than that of the El Chichon eruption in 1982. However, these influences are diminished after 1996 and are not relevant to more recent ozone depletion.

The other major natural influence on ozone is the solar cycle. Figure 2 shows the solar cycle to have an effect of $\sim 1 \%$ on ozone as it goes from minimum to maximum. This effect is smaller than found in other studies (see Brunner et al., 2006b, and discussion in Chipperfield and Fioletov, 2007). This difference is not important in terms of the longer-term ozone depletion, but it is important when considering the ozone increase since the mid-1990s. Interestingly Dhomse et al. (2006; see Fig. 10) calculate a slightly smaller solar cycle coefficient when using EESC rather than linear trends. Understanding and quantifying the impact of the solar cycle on stratospheric ozone remains a puzzle.

Dynamical changes seem to have affected ozone trends over Europe more than other parts of the northern midlatitudes (Appenzeller et al., 2000; Staehelin et al., 2001; Chipperfield and Randel, 2003), and so these were of immediate interest to the EU CANDIDOZ project. Analysis of the long-term total ozone records at 8 European Dobson stations shows that the influence of dynamic processes could account for perhaps $30 \%$ of the total trends calculated for the period 1970-2002 (Fig. 3 in Wohltmann et al., 2005). The regional behaviour is confirmed in the expanded study of 49 stations globally (Wohltmann et al., 2007) and consistent with the analysis of Orsolini and Doblas-Reyes (2003 see below) who estimated that this contribution was as high as 70\% over southwestern Europe (for 1979-2000), but more like $30 \%$ for the entire European sector. The finding that changing dynamics has been an important influence on ozone trends in the 1980s and 1990s is consistent with the conclu- sions of WMO 2006, as well as the more recent work of Hudson et al. (2006) who argue that dynamically-induced ozone changes of $-35 \%$ (1979-1991; less for longer periods) are caused by the northward shift of ozone regimes defined by the sub-tropical and polar fronts.

\subsubsection{Ozone evolution since the mid-1990s}

Figure 2 shows that the trend change in the Northern Hemisphere is primarily related to processes other than the small decrease which has occurred since the EESC peaked in 1997. This conclusion is supported by a number of CANDIDOZ and other studies and is also reached in the 2006 WMO/UNEP Ozone Assessment (Chipperfield and Fioletov, 2007). For example, our more detailed analyses of total ozone measurements by satellites (Dhomse et al., 2006; Brunner et al., 2006b) show that (i) the chemical turn-around in gas-phase chemistry is not the dominant contribution when dynamical processes are properly accounted, and (ii) changes in ozone transport, polar chemistry and the solar cycle are together responsible for nearly all the observed total ozone increases in northern mid-latitudes.

One of the main conclusions of Dhomse et al. (2006) is that increased wave-driving (leading to a faster stratospheric circulation) has caused much of the increase in total ozone over northern mid-latitudes since the mid-1990s. The rising solar cycle after 1996 is also important. Identical goodness of fits are found for the period 1979-2003 whether using monthly linear trend terms or the EESC term underlining that the difficulty in distinguishing the effect of ODS on the ozone record to date. Brunner et al. (2006b) examine this issue further using the approaches put forward by Weatherhead et al. (2000), Newchurch et al. (2003) and Reinsel et al. (2005), and they conclude that (a) EESC is a better explanatory variable of recent ozone changes than a single linear trend and (b) it is not the major contributor to the recent increase in ozone as also seen in Fig. 2.

The conclusions of these statistical analyses of observations are supported by a SLIMCAT modelling study which compared total ozone observations with total ozone for a simulation driven by ERA-40 winds and temperatures, but without chemical ozone depletion from ODS (Fig. 3, updated from Hadjinicolaou et al., 2005). The ozone trends at northern mid-latitudes prior to the mid-1990s were found to be $\sim 30 \%$ caused by dynamical changes, leaving $\sim 70 \%$ caused by ODS chemistry. The dynamic influence on the trend during this first period does not seem to be due to a radiative feedback resulting from the chemical ozone loss itself (Braesicke and Pyle, 2003). Since the mid-1990s effectively all the increase can be explained by dynamic changes. The companion simulation with full chemistry (red line in Fig. 3) shows no evidence for significant chemical recovery due to the turnaround in ODS. These results are consistent with the conclusions of a separate simulation of full chemistry with SLIMCAT (Feng et al., 2006) and with 2-D and 3-D GCM 


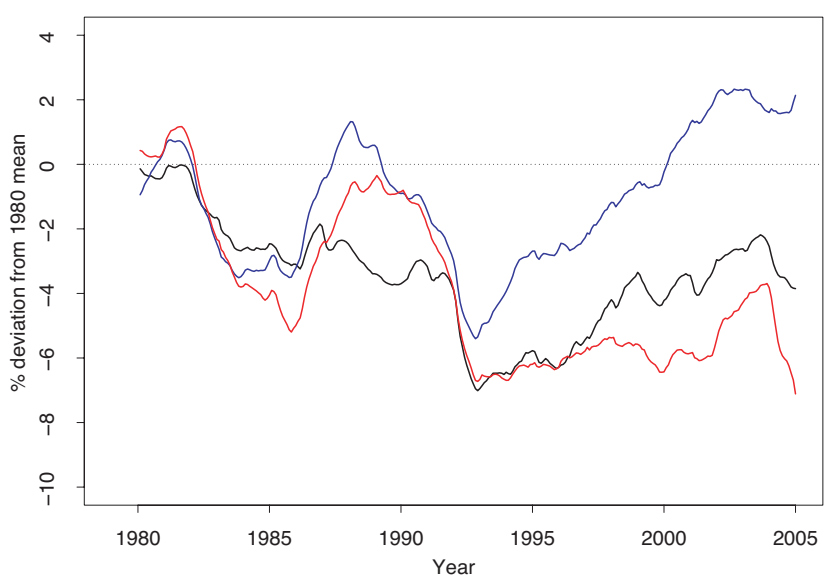

Fig. 3. Monthly mean column anomalies of SLIMCAT ozone (simple gas-phase, blue; full chemistry, red) and merged TOMS and SBUV observations (black) between $35^{\circ}-60^{\circ} \mathrm{N}$. The anomalies have been smoothed with a 24 -month running mean to average both over the annual cycle and the QBO (Updated from Hadjinicolaou et al., 2005).

model simulations (e.g. Andersen et al., 2006; Chipperfield and Randel, 2003; Weatherhead and Andersen, 2006) which show little anticipated effect of the decreasing EESC to date. Thus both the modeling and the statistical studies conclude that the magnitude of the observed increase in total ozone is too large for it to have been caused by the small decrease in EESC since the mid-1990s.

Different levels in the vertical distribution of ozone are affected to varying degrees by dynamics and chemistry. In the upper stratosphere ozone trends are expected to be less influenced by changes in dynamics and therefore more directly affected by ODS. Newchurch et al. (2003) analysed satellite and ground-based measurements of upper stratospheric ozone and found statistically significant change in ozone trends consistent with a slow-down in upper stratospheric $\mathrm{HCl}$. Zanis et al. (2006) used similar techniques in their analysis of the revised Umkehr record from Arosa and found changes in upper stratospheric ozone trends after 1996. These are not, however, $95 \%$ statistically significant after the aerosol correction has been applied to the retrieved data (Fig. 4). This lack of a significant change in trend during the recent period in the upper stratosphere is regionally coherent with recent results derived from upper stratospheric ozone data recorded by lidars, microwave radiometers and satellite instruments over Europe (Steinbrecht et al., 2006). Zanis et al. (2006) conclude that it is too early to say whether a "chemical" turnaround in upper stratospheric ozone has occurred although the results are clearly consistent with the decreasing EESC. It is possible that the lack of significance in these results is due to the greater variability inherent in a record (albeit a long one) at a single site as globally upper stratospheric trends do seem to have reversed (Newchurch et al., 2003; Steinbrecht et al., 2006).

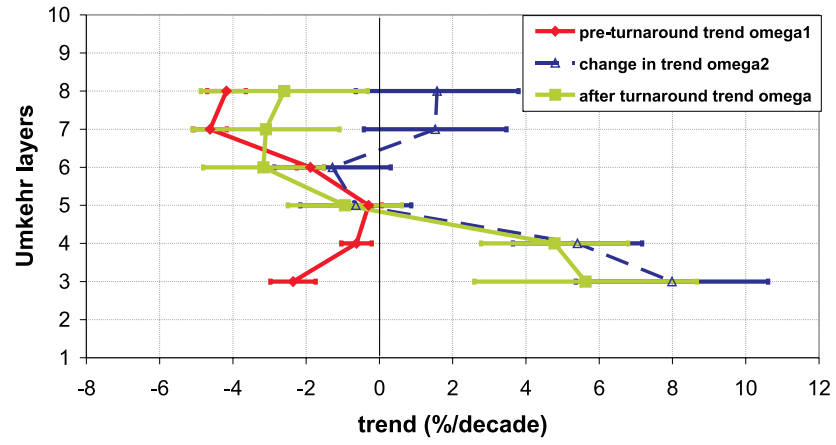

Fig. 4. Vertical distribution of year round ozone trend estimates in \%/decade deduced from Umkehr measurements at Arosa using the double trend model. The pre-turnaround trend estimates are in red, the change in trend estimates are in blue and those after the turnaround are in pink. The statistical model includes QBO, solar cycle and the equivalent latitude proxy as explanatory variables. The equivalent latitude proxy accounts for dynamics related ozone variability. The error bars denote 2 -sigma standard errors. The layer 3 represents the sum of layers L2 and L3 while the layer 8 represents the sum of layers L8, L9, and L10 (adapted from Zanis et al., 2007).

In the lower stratosphere, Zanis et al. (2006) found that the year-round trends over Arosa also become positive and, in particular, are more positive during the winter to spring period (Fig. 4). This change in trend is observed over Canada (Tarasick et al., 2005) and in the entire northern extra-tropical lower stratosphere (Yang et al., 2006; Terao and Logan, 2007). Yang et al. (2006) found that the half of the increase in total ozone is due to changed dynamics below $18 \mathrm{~km}$, while the timing and magnitude of the observed changes in ozone above $18 \mathrm{~km}$ altitude are consistent with the EESC evolution. Their estimate of the contribution from EESC to the change in total ozone is somewhat greater than those made in the various CANDIDOZ studies, but it is hard to know how significant this difference is without a more rigorous comparison of (i) the altitude ranges and time periods considered, and (ii) the details of the statistical models.

The timing of the change in the lower stratosphere ozone trend coincides with a change in the trend in the frequency of laminae occurrence (Krizan and Lastovicka, 2005; Tarasick et al., 2005). Laminae occur principally at altitudes below $20 \mathrm{~km}$, and changes in their frequency are likely to be caused by changes in lower stratospheric dynamics in the Northern Hemisphere. No such change is observed in the Southern Hemisphere (Krizan and Lastovicka, 2006).

\subsubsection{Links to climate patterns}

It has long been recognised that low-frequency tropospheric dynamics contributes to ozone column variability in the Northern Hemisphere, with most early studies focusing on the impact of the North Atlantic Oscillation or the Arctic 
Oscillation. More recent studies, based on both groundbased ozone time series analysis (Appenzeller et al., 2000; Bronnimann et al., 2000; Hansen and Svenoe, 2005; Steinbrecht et al., 2001; Wohltmann et al., 2007) and TOMS satellite observations (Orsolini and Doblas-Reyes, 2003) have shown that a variety of climate patterns and teleconnections leads to strong regional signatures over the Euro-Atlantic sector.

Orsolini and Doblas-Reyes (2003) demonstrated that up to $70 \%$ of the local ozone negative trends over Europe in spring were related to changes in four leading climate patterns. Inclusion of these four leading patterns captured the springtime decrease in ozone over Western Europe (defined as $40^{\circ} \mathrm{N}-60^{\circ} \mathrm{N}, 15^{\circ} \mathrm{W}-15^{\circ} \mathrm{E}$ ) in $1979-1997$, and the increase in the late nineties, following the absolute minimum in spring 1997, which was caused by an anomalous EastAtlantic pattern (Fig. 5). Jrrar et al. (2006) derived the spatial characteristics of Northern Hemisphere total ozone from a SLIMCAT run driven by ERA-15 reanalyses. Use of the corresponding principal components in a trend analysis revealed the importance of the polar night jet and, secondly, the Scandinavian pattern in dynamically driven trends at middle latitudes in winter and spring. In addition, Orsolini (2004) and Bronnimann et al. (2004) showed the remote influence of meteorological phenomena over the North Pacific, such as fluctuations in the Aleutian Low or El-Niño episodes, upon ozone variability in the Euro-Atlantic sector. The former study showed that inter-annual ozone variations between the North Pacific and Northern Europe were associated with an Aleutian-Icelandic seesaw-like variability, and were considerably larger in February than those associated with the Arctic Oscillation. How these findings link to the proposed movement of the sub-tropical and polar jets (Hudson et al., 2006) remains to be seen. For example, the Aleutian-Icelandic seesaw influences strongly the jet streams, and the storm tracks (Honda et al., 2001; Orsolini, 2004) over both oceans, but also has a strong signature on ozone columns over the North Atlantic.

\subsection{Long-term changes in the Arctic stratosphere}

The knowledge about Arctic ozone loss has increased enormously over the last decade or so as a result of several large field measurement campaigns (e.g. Newman et al., 2001) and through improved monitoring in the Arctic region particularly with ozonesondes and satellites. Ozone in polar regions can be rapidly destroyed by heterogeneous reactions occurring on polar stratospheric clouds (PSCs). These processes take place in the polar vortex, which forms every winter over the poles and the extent of the ozone loss is determined by a number of chemical and dynamical factors. Today we know that the strong interannual variability of Arctic ozone depletion depends on the following factors:

1. The temperature of the polar vortex and formation (if cold enough) of PSCs;

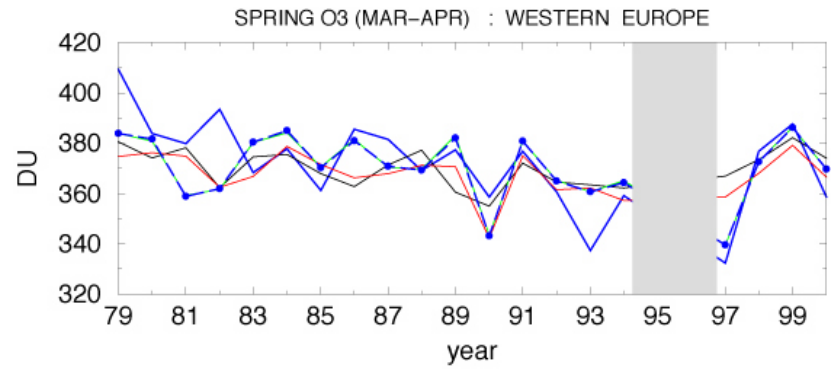

Fig. 5. Spring ozone over Western Europe $\left(40^{\circ} \mathrm{N}-60^{\circ} \mathrm{N}, 15^{\circ} \mathrm{W}-\right.$ $15^{\circ} \mathrm{E}$ ) from TOMS data (thick blue line) for 1979 to 2000 ; reconstructed spring ozone with anomalies from the four leading EuroAtlantic patterns successively added to the climatological mean: i.e. including the NAO (black), plus the Scandinavian pattern (red), plus the East-Atlantic pattern (green) and the European blocking pattern (thick blue dashed). The combined curve (thick blue dashed) best tracks the observed ozone variations (thick blue line), albeit the last pattern brings little change over that region (adapted from Orsolini and Doblas-Reyes, 2003).

\section{The duration and extent of PSCs each winter; and}

3. The longevity of the polar vortex into spring.

The variation in these factors since 1965 is shown Fig. 6ac. The chemical ozone loss has been calculated for nearly every winter since 1991 (Fig. 6d). A remarkably tight, linear relation is found between the chemical ozone loss and the volume of PSCs present that winter (Rex et al., 2004, 2006). For each cooling of $1 \mathrm{~K}$, an additional 15 Dobson Units of depletion in the ozone column is anticipated. This effect was three times larger than calculated in atmospheric models at that time (Rex et al., 2004): model improvements have since resulted in much better agreement (Newman and Rex, 2007). Further long term cooling in the Arctic winter stratosphere had resulted in a three-fold increase in PSCs, so that the stratospheric climate conditions had become significantly more favourable for ozone loss since the 1960s, an effect which considerably amplified the influence of the increasing halogen loading of the stratosphere. If these temperature trends continue into the future, Arctic ozone losses would increase until 2010-2015 and decrease only slowly afterwards (Knudsen et al., 2004). However, the cooling does not appear to be happening in all years - rather a pattern is emerging wherein the cold years get colder, but the warm years are not changing (Rex et al., 2006). In other words, the potential for severe losses in the Arctic seems to be increasing, but only in the $20 \%$ or so of coldest winters.

Decadal variations in the polar vortex have been analysed using ERA-40 reanalysis data from 1957 to 2002 (Karpetchko et al., 2005). In general, the large interannual variability is the dominant feature, obscuring any long-term changes. However, some features can be distinguished. For example, the average PSC existence in the Arctic increased from 1959 to 2002, but no statistically significant trends 

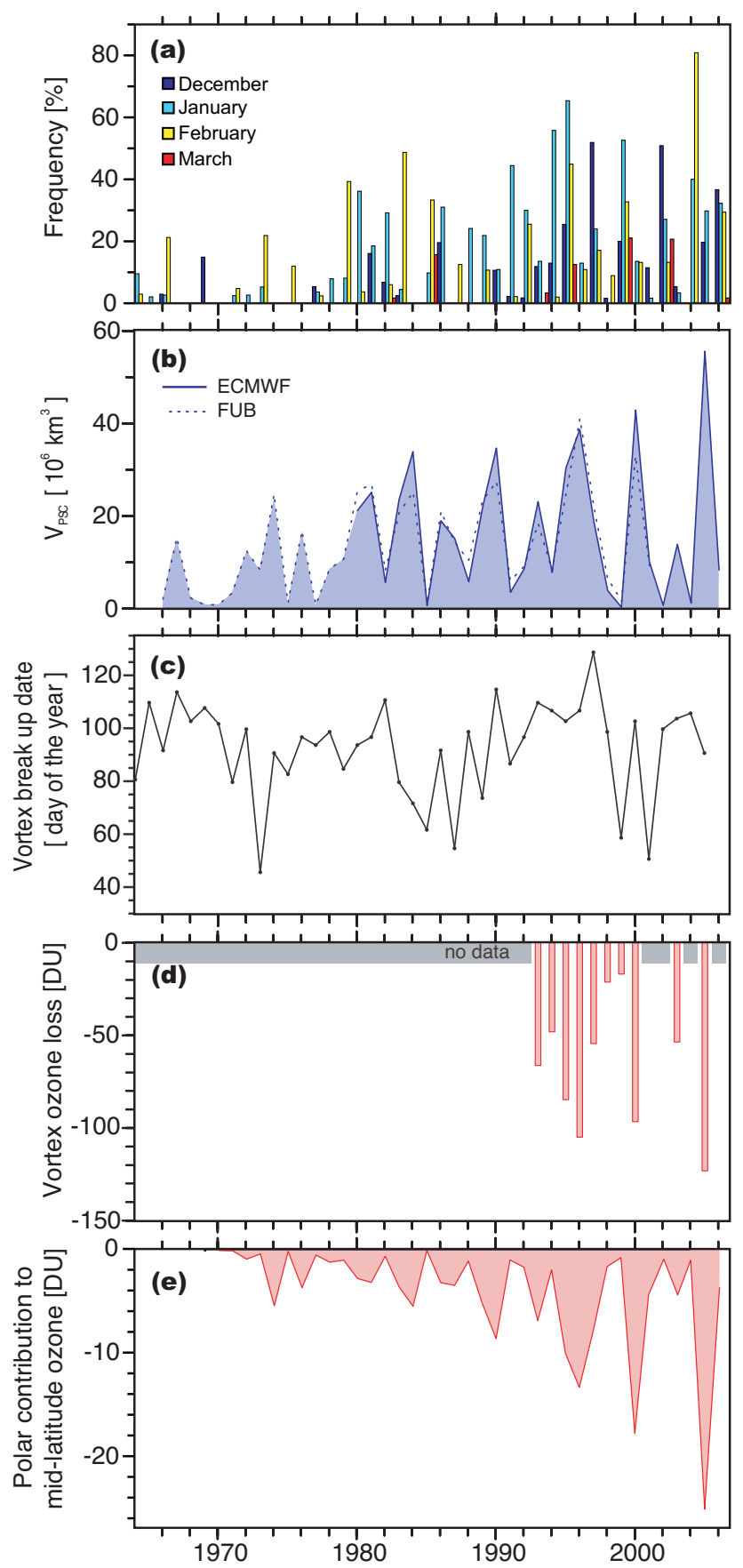

Fig. 6. The evolution of vortex properties underlying chemical ozone loss are shown in the the top three panels: (a) inferred PSC existence at $50 \mathrm{hPa}$ in the winter months derived from temperature measurements made by radiosondes at Sodankylä, Finland; (b) inferred volume of PSCs derived from ECMWF (solid) for 19792006 and FU Berlin (dashed) for 1966-2001 as in Rex et al. (2004); and (c) vortex break-up dates (updated from Karpetchko et al., 2005). The interannual variation of ozone loss is shown in the lower two panels: (d) the chemical ozone loss in the vortex estimated from observations of ozone using the vortex average approach (Rex et al., 2004); and (e) the estimated impact on mid-latitude ozone columns in May using the approach of Wohltmann et al. (2007). in size, temperature and duration were found for 19792002. Statistically significant increases $(95 \%$ error probability) were found in vortex duration, vortex size and PSC area in the lower stratosphere for March for 1979-1997 but not for 1979-2002. The lack of an overall trend in PSC existence is consistent with the analysis of Rex et al. (2006) who argue that, while there is no trend in most winters, more PSCs are now formed in the extremely cold winters.

Identification of long-term changes in the Arctic winter stratosphere is tricky due to multi-annual climate variability, and a strong dependence on the length of the record being considered is again found in analyses of the re-evaluated Arctic ozonesonde record. Statistically significant decreases in stratospheric ozone occurred over 1989-1997, but not for the period from 1989-2003 as lower stratospheric ozone increased significantly from the mid-1900s (Kivi et al., 2007). The ozone decreases and increases are strongly correlated with the tropopause height and this dynamical influence is the largest influence on the variance of stratospheric ozone in the Arctic winter/spring (Kivi et al., 2007). Tropopause variations may not, however, explain the long term changes in ozone in the absence of a trend in tropopause height. Other explanatory variables are then needed (see also Tarasick et al., 2005). Kivi et al. (2007) also found a significant correlation with the measures for chemical polar ozone depletion (accounting for up to 50\% of ozone variability in March) and the strength of the stratospheric circulation. In the Arctic troposphere a statistically significant increase of $12 \%$ is observed from 1989 to 2003, with the largest changes in January-April.

The strong correlation between the ozonesonde measurements and tropopause height is probably another manifestation of the influence of the low frequency tropospheric patterns found in total ozone data (Orsolini and Doblas-Reyes, 2003). These patterns (e.g. the North Atlantic Oscillation) are associated with anomalies in the tropopause height and so contribute significantly to the ozone variability. Again, decadal trends in the occurrence of the NAO and in ozone are found over the first part of record (up to the mid-1990s), but they become insignificant when recent years are included.

Ozone loss in the Arctic vortex can contribute to reduced ozone amounts over mid-latitudes when ozone-depleted air is transported from high to middle latitudes. The magnitude of this has been estimated in several trend studies described in Sect. 3.1 and in modelling studies (Hadjinicolaou and Pyle, 2004). Figure 6e shows estimates based on the analysis in Wohltmann et al. (2007), and the interannual variation is clearly a dominant feature (see also Fig. 2). However, it is hard to develop a reliable process-based indicator which takes into account all the chemical and dynamical factors involved. In CANDIDOZ, this has also been investigated in a series of case studies of individual winters which concluded that dilution can explain $29 \%$ of the overall trend over mid-latitudes in total ozone from 1979-1997 (Andersen and Knudsen, 2006). It should be noted that this fraction 
depends quite strongly on the period being considered because Arctic ozone loss varies substantially from year to year. For example, Fioletov and Shepherd (2005) estimate a 15\% contribution for the period 1979-2003. Within the considerable uncertainties, these estimates are consistent with those found in the statistical studies using a VPSC*EESC proxy.

\section{Discussion and conclusions}

The large dynamical influence on decadal changes in ozone over the last 25 years means that any meaningful discussion of recovery has to be carried out with reference to the effects of the Montreal Protocol. While, the importance of dynamical influences on ozone trends has been recognised for some time, the difficulties in quantifying the impact has led to past trends being generally attributed to halogen chemistry with an implicit assumption that any uncertainties resulting from interannual changes in dynamics are adequately represented in the error bars associated with the trend estimates. This assumption holds as long as the underlying dynamical behaviour (and variability) does not change over the period under consideration. However, if changes are occurring on decadal timescales, then this no longer holds true.

The observational record shows unambiguously that total ozone over northern mid-latitudes decreased from 1980 to the mid-1990s. Since then it has increased significantly. Statistical and modeling studies carried out in CANDIDOZ show that the main cause of this change in ozone trends results from changed dynamical behaviour. Unambiguously ascribing part of these decadal ozone changes to a certain dynamical driver is hard because dynamical processes are physically coupled in the atmosphere in a complex way that is hard to represent in simple statistical models (e.g. Mäder et al., 2007). Further, chemical ozone depletion and dynamical changes are not always independent: the strength of the Brewer-Dobson circulation, for example, is closely connected with polar ozone depletion through its influence on polar vortex temperatures. Separating the effects of EP flux changes from the interannual variability of polar ozone depletion is therefore difficult (Dhomse et al., 2006; Brunner et al., 2007; Wohltmann et al., 2007). Further, quantification of the effect of EP flux on total ozone at mid-latitudes depends quite sensitively on the period over which the EP flux is integrated: those studies which integrate over the whole winter, i.e. from October or November (Brunner et al., 2006b; Wohltmann et al., 2007) find smaller changes in EP flux prior to the mid-1990s than those which integrate from January onward (Randel et al., 2002; Dhomse et al., 2006).

The amount of halogen in the stratosphere (as measured by EESC) peaked in 1997 and by 2004 had fallen by about $6 \%$ as a result of the application of the Montreal Protocol. On current understanding this change is not sufficient to explain all (or even most) of the changed trend in total ozone over the last 10 years. We would expect the chemical ozone trend resulting from changes in EESC to have flattened in the late 1990s, and there is some evidence in the observational record that this has occurred.

Similar considerations apply in the Arctic. Here, the ozone loss in any winter is principally determined by the temperature in the Arctic vortex and by how many PSCs form. Superimposed on these large year-to-year variations is the much slower decline in EESC. In the absence of any trend in the physical nature of the vortex, a slow reduction in average Arctic ozone loss would be expected. To date, no trend has been found in characteristics such as vortex strength, size or persistence. However, the cold winters are growing colder and the ozone losses in those years are getting larger. Until the mechanism for this trend is understood, it is impossible to say what the future implications are.

The total ozone column is sensitive to changes in the large-scale stratospheric circulation which is driven by tropospheric forcing. If, as some models suggest, the speed of this circulation increases (Schnadt and Dameris, 2003; Braesicke et al., 2006), then there will be enhanced ozone columns at mid and high latitudes and reduced chemical ozone loss in the (warmer) Arctic stratosphere. However, predicting the effect of changed tropospheric forcing is not simple, and it causes much of the disagreement between models (Andersen et al., 2006). A cooler lower stratosphere resulting from increased levels of greenhouse gases could lead to a reduced circulation. Either way, the resulting impact on the ozone column could be several percent and be similar to the changes that have occurred as a result of ODS outside the regions of severe polar loss.

Analyses of past meteorological records show that the tropopause height has increased since the 1950s and that there has been an acceleration since the 1970s. While some of this is related to the decrease in lower stratospheric ozone, much is attributable to the radiative effect of $\mathrm{CO}_{2}$ and other long-lived greenhouse gases (Santer et al., 2003). This effect is larger at higher latitudes and is likely to continue as greenhouse gas levels rise. The ozone column is sensitive to tropopause height and a rising tropopause will lead to reduced ozone levels. If the average tropopause height does not change, then to first order regional changes will lead to a redistribution of ozone. If on average the tropopause becomes higher, the stratosphere will be smaller and there will likely be reduced ozone amounts (and higher UV). Regional differences in this behaviour can be expected to continue.

In summary, the Montreal Protocol has already reduced emissions of ODS and caused their atmospheric concentrations to start to fall. CANDIDOZ and other recent studies of ozone trends are starting to show that the Montreal Protocol is starting to have a discernible effect on stratospheric ozone, though more years of measurements and analyses will be required before that can be shown unambiguously from ozone observations. Overall it can be confidently expected that the effects of ODS on ozone and UV will decline over the coming decades. However, changes in stratospheric circulation 
will continue to have a major impact on ozone and UV in the future, the importance of which will depend on the link between climate change and the stratosphere.

Acknowledgements. The authors thank DG Research of the European Commission for the support of the CANDIDOZ project (EVK2-CT-2001-00133) and for continued support in the frame of the SCOUT-O3 Integrated Project (505390-GOCE-CT-2004). We thank J. Daniel (NOAA) for supplying the ODS production figures and EESC data used in the 2006 WMO Scientific Assessment of Ozone Depletion.

Topical Editor U.-P. Hoppe thanks D. Tarasick and another anonymous referee for their help in evaluating this paper.

\section{References}

Andersen, S. B., Weatherhead, E. C., Stevermer, A., Austin, J., Brühl, C., Fleming, E. L., de Grandpré, J., Grewe, V., Isaksen, I., Pitari, G., Portmann, R. W., Rognerud, B., Rosenfield, J. E., Smyshlyaev, S., Nagashima, T., Velders, G. J. M., Weisenstein, D. K., and Xia, J.: Comparison of recent modeled and observed trends in total column ozone, J. Geophys. Res., 111, D02303, doi:10.1029/2005JD006091, 2006.

Andersen, S. B. and Knudsen, B. M.: The influence of polar vortex ozone depletion on NH midlatitude ozone trends in spring, Atmos. Chem. Phys., 6, 2837-2845, 2006,

http://www.atmos-chem-phys.net/6/2837/2006/.

Appenzeller, C., Weiss, A. K., and Staehelin, J.: North Atlantic Oscillation modulates total ozone winter trends, Geophys. Res. Lett., 27, 1131-1134, 2000.

Bhartia, P. K., Wellemeyer, C. G., Taylor, S. L., Nath, N., and Gopalan, A.: Solar Backscatter Ultraviolet (SBUV) Version 8 profile algorithm, in: Proceedings of the XX Quadrennial Ozone Symposium, edited by: Zerefos, C., pp. 295-296, Univ. of Athens, Greece, 2004.

Braesicke, P. and Pyle, J. A.: Changing ozone and changing circulation in northern mid-latitudes: Possible feedback?, Geophys. Res. Lett., 30, 1059, doi:10.1029/2002GL015973, 2003.

Braesicke, P., Hurwitz, M. M., and Pyle, J. A.: The stratospheric response to changes in ozone and carbon dioxide as modelled with a GCM including parameterised ozone chemistry, Meteorol. Z., 15, 343-354, doi:10.1127/0941-2948/2006/0124, 2006.

Bronnimann, S., Luterbacher, J., Schmutz, C., and Wanner, H.: Variability of total ozone at Arosa, Switzerland, since 1931 related to atmospheric circulation indices, Geophys. Res. Lett., 27, 2213-2216, 2000.

Bronnimann, S., Luterbacher, J., Staehelin, J., Svendby, T. M., Hansen, G., and Svenøe, T.: Extreme climate of the global troposphere and stratosphere in 1940-42 related to El Nino, Nature, 431(7011), 971-974, 2004.

Brunner, D., Staehelin, J., Künsch, H.-R., and Bodeker, G. E.: A Kalman filter reconstruction of the vertical ozone distribution in an equivalent latitude - potential temperature framework from TOMS/GOME/SBUV total ozone observations, J. Geophys. Res, 111, D12308, doi:10.1029/2005JD006279, 2006a.

Brunner, D., Staehelin, J., Maeder, J. A., Wohltmann, I., and Bodeker, G. E.: Variability and trends in total and vertically resolved stratospheric ozone based on the CATO ozone data set,
Atmos. Chem. Phys., 6, 4985-5008, 2006b, http://www.atmos-chem-phys.net/6/4985/2006/.

Chipperfield, M. P. and Randel, W. J. (Lead Authors), Bodeker, G. E., Dameris, M., Fioletov, V. E., Friedl, R. R., Harris, N. R. P., Logan, J. A., McPeters, R. D., Muthama, N. J., Peter, T., Shepherd, T. G., Shine, K. P., Solomon, S., Thomason, L. W., and Zawodny, J. M.: Chapter 4 in Scientific Assessment of Ozone Depletion: 2002, WMO Global Ozone Research and Monitoring Project Report No. 47, Geneva, 2003.

Chipperfield, M. P. and Fioletov, V. E. (Lead Authors), Bregman, B., Burrows, J., Connor, B. J., Haigh, J. D., Harris, N. R. P., Hauchecorne, A., Hood, L. L., Kawa, S. R., Krzyscin, J. W., Logan, J. A., Muthama, N. J., Polvani, L., Randel, W. J., Sasaki, T., Sthelin, J., Stolarski, R. S., Thomason, L. W., and Zawodny, J. M.: Chapter 3 in Scientific Assessment of Ozone Depletion: 2006, WMO Global Ozone Research and Monitoring Project Report No. 50, Geneva, 2007.

Coldewey-Egbers, M., Weber, M., Buchwitz, M., and Burrows, J. P.: Application of a modified DOAS method for total ozone retrieval from GOME data at high polar latitudes, Adv. Space Res., 34, 749-753, 2004.

Coldewey-Egbers, M., Weber, M., Lamsal, L. N., de Beek, R., Buchwitz, M., and Burrows, J. P.: Total ozone retrieval from GOME UV spectral data using the weighting function DOAS approach, Atmos. Chem. Phys., 5, 5015-5025, 2005, http://www.atmos-chem-phys.net/5/5015/2005/.

Crutzen, P. J.: Ozone production rates in an oxygen-hydrogennitrogen oxide atmosphere, J. Geophys. Res., 76, 7311-7327, 1971.

Dhomse, S., Weber, M., Wohltmann, I., Rex, M., and Burrows, J. P.: On the possible causes of recent increases in northern hemispheric total ozone from a statistical analysis of satellite data from 1979 to 2003, Atmos. Chem. Phys., 6, 1165-1180, 2006, http://www.atmos-chem-phys.net/6/1165/2006/.

Farman, J. C., Gardiner, B. G., and Shanklin, J. D.: Large losses of total ozone in Antarctica reveal seasonal $\mathrm{C} 1 \mathrm{O}_{\mathrm{X}} / \mathrm{NO}_{\mathrm{X}}$ interaction, Nature, 315, 207-210, 1985.

Feng, W., Chipperfield, M. P., Dorf, M., and Pfeilsticker, K.: Studies of mid-latitude ozone changes using a 3D CTM and ERA-40 analyses, Atmos. Chem. Phys. Discuss., 6, 6695-6722, 2006, http://www.atmos-chem-phys-discuss.net/6/6695/2006/.

Fioletov, V. E. and Shepherd, T. G.: Summertime total ozone variations over middle and polar latitudes, Geophys. Res. Lett., 32, L04807, doi:10.1029/2004GL022080, 2005.

Fusco, A. C. and Salby, M. L.: Interannual variations of total ozone and their relationship to variations of planetary wave activity, J. Climate, 12, 1619-1629, 1999.

Hadjinicolaou, P. and Pyle, J. A.: The Impact of Arctic Ozone Depletion on Northern Middle Latitudes: Interannual Variability and Dynamical Control, J. Atmos. Chem., 47(1), 25-43, 2004.

Hadjinicolaou, P., Pyle, J. A., and Harris, N. R. P.: The recent turnaround in stratospheric ozone over northern middle latitudes: a dynamical modelling perspective, Geophys. Res. Lett., 32, L12821, doi:10.1029/2005GL022476, 2005.

Hansen, G. and Svenøe, T.: Multilinear regression analysis of the 65-year Troms $\varnothing$ total ozone series, J. Geophys. Res., 110, D10103, doi:10.1029/2004JD005387, 2005.

Harris, N. R. P., Ancellet, G., Bishop, L., Hofmann, D. J., Kerr, J. B., McPeters, R. D., Prendez, M., Randel, W., Staehelin, J., 
Subbaraya, B. H., Volz-Thomas, A., Zawodny, J., and Zerefos, C. S.: Trends in Stratospheric and Tropospheric Ozone, J. Geophys. Res., 102, 1571-1590, 1997.

Hofmann, D. J. and Pyle, J. A.: Chapter 12 in WMO Scientific Assessment of Ozone Depletion: 1998, WMO Global Ozone Research and Monitoring Project Report No. 44, Geneva, 1999.

Honda, M., Nakamura, H., Ukita, J., Kousaka, I., and Takeuchi, K.: Interannual Seesaw between the Aleutian and Icelandic Lows. Part I: Seasonal Dependence and Life Cycle, J. Climate, 14, 1029-1042, 2001.

Hood, L. L., McCormack, J. P., and Labitzke, K.: An investigation of dynamical contributions to midlatitude ozone trends in winter, J. Geophys. Res., 102, 13 079-13 093, 1997.

Hudson, R. D., Andrade, M. F., Follette, M. B., and Frolov, A. D.: The total ozone field separated into meteorological regimes - Part II: Northern Hemisphere mid-latitude total ozone trends, Atmos. Chem. Phys., 6, 5183-5191, 2006, http://www.atmos-chem-phys.net/6/5183/2006/.

Johnston, H.: Reductions of stratospheric ozone by nitrogen oxide catalysts from supersonic transport exhaust, Science, 173, 517522, 1971 .

Jrarr, A., Braesicke, P., Hadjinicolaou, P., and Pyle, J. A.: Trend analysis of CTM-derived northern hemisphere winter total ozone using self-consistent proxies: How well can we explain dynamically induced trends?, Q. J. Roy. Meteorol. Soc., 132, 19691983, doi:10.1256/qj.05.136, 2006.

Karpetchko, A., Kyro, E., and Knudsen, B.: Arctic and Antarctic polar vortices 1957-2002 as seen from the ERA-40 reanalyses, J. Geophys. Res., 110, D21109, doi:10.1029/2005JD006113, 2005.

Kivi, R., Kyrö, E., Turunen, T., Harris, N. R. P., von der Gathen, P., Rex, M., Andersen, S. B., and Wohltmann, I.: Ozonesonde observations in the Arctic during 1989-2003: Ozone variability and trends in lower stratosphere and free troposphere, J. Geophys. Res., 112, DO8306, doi:10.1029/2006JD007271, 2007.

Knudsen, B. M., Harris, N. R. P., Andersen, S. B., Christiansen, B., Larsen, N., Rex, M., and Naujokat, B.: Extrapolating future ozone losses, Atmos. Chem. Phys., 4, 1849-1856, 2004, http://www.atmos-chem-phys.net/4/1849/2004/.

Krizan, P. and Lastovicka, J.: Trends in positive and negative ozone laminae in the Northern Hemisphere, J. Geophys. Res., 110, D10107, doi:10.1029/2004JD005477, 2005.

Krizan, P. and Lastovicka, J.: Ozone laminae: Comparison of the Southern and Northern Hemisphere, and tentative explanation of trends, J. Atmos. Solar-Terr. Phys., 68, 1962-1972, 2006.

Mäder, J. A., Staehelin, J., Brunner, D., Stahel, W. A., Wohltmann, I., and Peter, T.: Statistical modelling of total ozone: Selection of appropriate explanatory variables, J. Geophys. Res., 112, D11108, doi:10.1029/2006JD007694, 2007.

Metelka, L., Vanicek, K., and Kliegrova, S.: Application of neural models for simulation of total ozone in the European region, Publication of the Czech Hydrometeorological Institute, Prague, ISBN: 80-86690-30-X, 2005.

Molina, M. J. and Rowland, F. S.: Stratospheric sink for chlorofluoromethanes, chlorine atom catalysed destruction of ozone, Nature, 249, 810-812, 1974.

Newchurch, M. J., Yang, E.-U., Cunnold, D. M., Reinsel, G. C., Zawodny, J. M., and Russell III, J. M.: Evidence for slowdown in stratospheric ozone loss: First stage of ozone recovery, J. Geophys. Res., 108, 4507, doi:10.1029/2003JD003471, 2003.
Newman, P. A., Harris, N. R. P., Adriani, A., Amanatidis, G. T., Anderson, J. G., Braathen, G. O., Brune, W. H., Carslaw, K. S., Craig, M. S., DeCola, P. L., Guirlet, M., Hipskind, R. S., Kurylo, M. J., Küllmann, H., Larsen, N., Mégie, G. J., Pommereau, J.-P., Poole, L. R., Schoeberl, M. R., Stroh, F., Toon, O. B., Trepte, C. R., and Van Roozendael, M.: An overview of the SOLVE-THESEO 2000 campaign, J. Geophys. Res., 107, 8259, doi:10.1029/2001JD001303, 2002.

Newman, P. A., Nash, E. R., Kawa, S. R., Montzka, S. A., and Schauffler, S. M.: When will the Antarctic hole recover?, Geophys. Res. Lett., 33, L12814, doi:10.1029/2005GL025232, 2006.

Newman, P. A., Rex, M., Canziani, P. O., Carslaw, K. S., Drdla, K., Godin-Beekmann, S., Golden, D. M., Jackman, C. H., Kreher, K., Langematz, U., Müller, R., Nakane, H., Orsolini, Y. J., Salawitch, R. J., Santee, M. L., von Hobe, M., and Yoden, S.: Chapter 4 in Scientific Assessment of Ozone Depletion: 2006, WMO Global Ozone Research and Monitoring Project Report No. 50, Geneva, 2007.

Orsolini, Y. J. and Doblas-Reyes, F. J.: Ozone signatures of climate patterns over the Euro-Atlantic sector in the spring, Q. J. Roy. Meteor. Soc., 129, 3251-3263, 2003.

Orsolini, Y. J.: Seesaw Ozone Fluctuations between the North Pacific and Atlantic in Late Winter, J. Meteor. Soc. Japan, 82(3), 941-948, 2004.

Randel, W. J., Wu, F., and Stolarski, R.: Changes in column ozone correlated with the stratospheric EP flux, J. Meteorol. Soc. Japan, 80(4B), 849-862, 2002.

Reinsel, G. C., Weatherhead, E. C., Tiao, G. C., Miller, A. J., Nagatani, R. M., Wuebbles, D. J., and Flynn, L. E.: On detection of turnaraound and recovery in trend for ozone, J. Geophys. Res., 107, D10, doi:10.1029/2001JD000500, 2002.

Reinsel, G. C., Miller, A. J., Weatherhead, E. C., Flynn, L. E., Nagatani, R. M., Tiao, G. C., and Wuebbles, D. J.: Trend analysis of total ozone data for turnaround and dynamical contributions, J. Geophys. Res., 110, D16306, doi:10.1029/2004JD004662, 2005.

Rex, M., Salawitch, R. J., von der Gathen, P., Harris, N. R. P., Chipperfield, M. P., and Naujokat, B.: Arctic Ozone Loss and Climate Change, Geophys. Res. Lett., 31, LO4116, doi:10.1029/2003GL018844i, 2004.

Rex, M., Salawitch, R. J., Deckelmann, H., von der Gathen, P., Harris, N. R. P., Chipperfield, M. P., Naujokat, B., Reimer, E., Allaart, M., Andersen, S. B., Bevilacqua, R., Braathen, G. O., Claude, H., Davies, J., De Backer, H., Dier, H., Dorokov, V., Fast, H., Gerding, M., Godin-Beekmann, S., Hoppel, K., Johnson, B., Kyrö, E., Litynska, Z., Moore, D., Nakane, H., Parrondo, M. C., Risley, A. D., Skrivankova, P., Stübi, R., Viatte, P., Yushkov, V., and Zerefos, C.: Arctic Winter 2005: Implications for stratospheric ozone loss and climate change, Geophys. Res. Lett., 33, L23808, doi:10.1029/2006GL026731, 2006.

Rowland, F. S., Harris, N., Bojkov, R. D., and Bloomfield, P. B.: Statistical error analysis of ozone trends - Winter depletion in the northern hemisphere, in: Ozone in the Atmosphere, edited by: Bojkov, R. and Fabian, P., 71-75, A. Deepack, Hampton, VA., 1988.

Santer, B. D., Sausen, R., Wigley, T. M. L., Boyle, J. S., Achuta Rao, K., Doutriaux, C., Hansen, J. E., Meehl, G. A., Roeckner, C., Ruedy, R., Schmidt, G. and Taylor, K. E.: Behavior of tropopause height and atmospheric temperature in models, reanalyses and observations: Decadal changes, J. Geophys. Res., 
108, 4002, doi:10:1029/2002JD002258, 2003.

Schnadt, C. and Dameris, M.: Relationship between North Atlantic Oscillation changes and stratospheric ozone recovery in the Northern Hemisphere in a chemistry-climate model, Geophys. Res. Lett., 30(9), 1487, doi:10.1029/2003GL017006, 2003.

Staehelin, J., Harris, N. R. P., Appenzeller, C., and Eberhard, J.: Ozone trends: A review, Rev. Geophys., 39, 231-290, 2001.

Steinbrecht, W., Claude, H., and Köhler, U.: Correlations between tropopause height and total ozone: Implications for long-term changes, J. Geophys. Res., 103, 19 183-19 192, 1998.

Steinbrecht, W., Claude, H., Köhler, U., and Winkler, P.: Interannual changes of total ozone and northern hemisphere circulation patterns, Geophys. Res. Lett., 28, 1191-1194, 2001.

Steinbrecht, W., Claude, H., Schönenborn, F., McDermid, I. S., Leblanc, T., Godin, S., Song, T., Swart, D. P. J., Meijer, Y. J., Bodeker, G. E., Connor, B. J., Kämpfer, N., Hocke, K., Calisesi, Y., Schneider, N., de la Noë, J., Parrish, A. D., Boyd, I. S., Brühl, C., Steil, B., Giorgetta, M. A., Manzini, E., Thomason, L. W., Zawodny, J. M., McCormick, M. P., Russell III, J. M., Bhartia, P. K., Stolarski, R. S., and Hollandsworth-Frith, S. M.: Long-term evolution of upper stratospheric ozone at selected stations of the Network for the Detection of Stratospheric Change (NDSC), J. Geophys. Res., 111, D10308, doi:10.1029/2005JD006454, 2006.

Stolarski, R. S. and Cicerone, R. J.: Stratospheric chlorine: A possible sink for ozone, Can. J. Chem., 52, 1610-1615, 1974.

Stolarski, R. S. and Frith, S. M.: Search for evidence of trend slowdown in the long-term TOMS/SBUV total ozone data record: the importance of instrument drift uncertainty, Atmos. Chem. Phys., 6, 4057-4065, 2006,

http://www.atmos-chem-phys.net/6/4057/2006/.

Tarasick, D. W., Fioletov, V. E., Wardle, D. I., Kerr, J. B., and Davies, J.: Changes in the vertical distribution of ozone over Canada from ozonesondes: 1980-2001, J. Geophys. Res., 110, D02304, doi:10.1029/2004JD004643, 2005.

Terao, Y. and Logan, J. A.: Consistency of time series and trends of stratospheric ozone as seen by ozonesonde, SAGE II, HALOE, and SBUV(/2), J. Geophys. Res., 112, D06310, doi:10.1029/2006JD007667, 2007.

Uppala, S. M., Kållberg, P. W., Simmons, A. J., Andrae, U., da Costa Bechtold, V., Fiorino, M., Gibson, J. K., Haseler, J., Hernandez, A., Kelly, G. A., Li, X., Onogi, K., Saarinen, S., Sokka, N., Allan, R. P., Andersson, E., Arpe, K., Balmaseda, M. A., Beljaars, A. C. M., van de Berg, L., Bidlot, J., Bormann, N., Caires, S., Chevallier, F., Dethof, A., Dragosavac, M., Fisher, M., Fuentes, M., Hagemann, S., Hólm, E., Hoskins, B. J., Isaksen, L., Janssen, P. A. E. M., Jenne, R., McNally, A. P., Mahfouf, J.-F., Morcrette, J.-J., Rayner, N. A., Saunders, R. W., Simon, P., Sterl, A., Trenberth, K. E., Untch, A., Vasiljevic, D., Viterbo, P., and Woollen, J.: The ERA-40 Reanalysis, Q. J. Roy. Meteor. Soc., 131, 2961-3012, 2005.

Vanicek, K., Dubrovsky, M., and Stanek, M.: Evaluation of Dobson and Brewer total ozone observations from Hradec Králové, Czech Republic, 1961-2002, Publication of the Czech Hydrometeorological Institute, Prague, ISBN: 80-86690-10-5, 2003.
Vanicek, K.: Differences between ground Dobson, Brewer and satellite TOMS-8, GOME-WFDOAS total ozone observations at Hradec Králové, Czech, Atmos. Chem. Phys., 6, 5163-5171, 2006,

http://www.atmos-chem-phys.net/6/5163/2006/.

Vogler, C., Brönnimann, S., and Hansen, G.: Re-evaluation of the 1950-1962 total ozone record from Longyearbyen, Svalbard, Atmos. Phys. Chem., 6, 4763-4773, 2006.

Weatherhead, E. C., Reinsel, G. C., Tiao, G. C., Jackman, C. H., Bishop, L., Hollandsworth Frith, S. M., DeLuisi, J., Keller, T., Oltmans, S. J., Fleming, E. L., Wuebbles, D. J., Kerr, J. B., Miller, A. J., Herman, J., McPeters, R., Nagatani, R. M., and Frederick, J. E.: Detecting the recovery of total column ozone, J. Geophys. Res., 105, 22 201-22 210, 2000.

Weatherhead, E. C. and Andersen, S. B.: The search for signs of recovery of the ozone layer, Nature, 441, 39-45, doi:10.1038/nature04746, 2006.

Weber, M., Dhomse, S., Wittrock, F., Richter, A., Sinnhuber, B.-M., and Burrows, J. P.: Dynamic control of NH and SH winter/Spring total ozone from GOME observations in 1995-2002, Geophys. Res. Lett., 30, 1853, doi:10.1029/2002GL016799, 2003.

Weber, M., Lamsal, L. N., Coldewey-Egbers, M., Bramstedt, K., and Burrows, J. P.: Pole-to-pole validation of GOME WFDOAS total ozone with ground-based data, Atmos. Chem. Phys., 5, 1341-1355, 2005, http://www.atmos-chem-phys.net/5/1341/2005/.

Weiss, A. K., Staehelin, J., Appenzeller, C., and Harris, N. R. P.: Chemical and Dynamical Contributions to Ozone Profile Trends of the Payerne (Switzerland) balloon soundings, J. Geophys. Res., 106, 22 685-22 694, doi:10.1029/2000JD000106, 2001.

Wohltmann, I., Rex, M., Brunner, D., and Mäder, J.: Integrated equivalent latitude as a proxy for dynamical changes in ozone column, Geophys. Res. Lett., 32, L09811, doi:10:1029/2005/GL022497, 2005.

Wohltmann, I., Lehmann, R., Rex, M., Brunner, D., and Mäder, J.: A process-oriented regression model for column ozone, J. Geophys. Res., 112, D12304, doi:10.1029/2006JD007573, 2007.

World Meteorological Organization: Scientific Assessment of Ozone Depletion: 2002, WMO Global Ozone Research and Monitoring Project Report No. 47, Geneva, 2003.

World Meteorological Organization: Scientific Assessment of Ozone Depletion: 2006, WMO Global Ozone Research and Monitoring Project Report No. 50, Geneva, 2007.

Yang, E.-S., Cunnold, D. M., Salawitch, R. J., McCormick, M. P., Russell III, J., Zawodny, J. M., Oltmans, S., and Newchurch, M. J.: Attribution of recovery in lower-stratospheric ozone, J. Geophys. Res., 111, D17309, doi:10.1029/2005JD006371, 2006.

Zanis, P., Maillard, E., Staehelin, J., Zerefos, C., Kosimidis, E., Tourpali, K., and Wohltmann, I.: On the turnaround of stratospheric ozone trends deduced from the re-evaluated Umkehr record at Arosa, Switzerland, J. Geophys. Res., 111, D22307, doi:10.1029/2005JD006886, 2006. 